\title{
Effect of Age on Postoperative Results in Elderly Coronary By-pass Patients
}

\section{Koroner Baypas Hastalarında Postoperatif Sonuçlara Yaşın Etkileri}

Adil Polat ${ }^{1}$, Funda Gümüşs ${ }^{2}$ Hüseyin Kuplay ${ }^{1}$, Cihan Yücel ${ }^{1}$, Serkan Sönmez ${ }^{1}$, Seçkin Sarıŏlư ${ }^{1}$, Vedat Erentuğ ${ }^{1}$

\footnotetext{
${ }^{1}$ Department of Cardiovascular Surgery, Bagcilar Training and Research Hospital, Istanbul, Turkey

1 Bağcılar Eğitim ve Araştırma Hastanesi, Kalp ve Damar Cerrahisi Kliniği, İstanbul, Türkiye

2 Department of Anesthesia and Reanimation, Bagcilar Training and Research Hospital, Istanbul, Turkey

${ }^{2}$ Bağcılar Eğitim ve Araştırma Hastanesi, Anesteziyoloji ve Reanimasyon Kliniği, İstanbul, Türkiye
}

Yazıșma Adresi/

Correspondence

Dr. Adil Polat

Bağcılar Eğitim ve Araştırma Hastanesi Kalp ve Damar Cerrahisi Kliniği, Bağcılar, İstanbul-Türkiye

e-posta adilpol@yahoo.com

\section{ABSTRACT}

Introduction: The purpose of this study is to analyze the outcome results of coronary by-pass operations from a single institution. The post-operative neurologic complications have been analyzed in detail in order to find out the risk factors and the relation of age and occurrence of neurologic complications has been assessed.

Patients and Methods: In this retrospective study, we analyzed the prospectively collected data of 510 coronary by-pass patients. Neurological morbidity and mortality were evaluated with logistic regression analysis for elderly patients.

Results: Of these 510 patients, 382 (74.9\%) were male and 89 (17.5\%) were older than 70 years of age. Post-operative mortality, pulmonary and neurologic morbidity occurred in 27 (5.3\%), 78 (15.3\%) and $26(5.1 \%)$ patients, respectively. The comparison of patients with $\leq 70$ and $>70$ years of age showed that the differences were significant (mortality $4.0 \%$ vs. $11.2 \%, p=0.012$; pulmonary morbidity $13.5 \%$ vs. $23.6 \%, p=0.022$; neurologic morbidity $3.3 \%$ vs. $13.5 \%, p=$ 0.0001 ). Presence of cerebrovascular disease (odds ratio $=4.72 ; p=0.014$ ) and advanced age (odds ratio $=3.55 ; p=0.016$ ) were independent predictors of neurologic complications. Every year increase above 51.5 years of age was associated with $5.8 \%(p=0.049)$ increased neurologic complication risk.

Conclusion: Elderly patients have higher rates of mortality, pulmonary and neurologic morbidity after coronary by-pass operations. Although no significant associations were found between age and mortality, age constitutes an independent risk factor for neurologic morbidity along with presence cerebrovascular disease.

Key Words: Coronary artery by-pass grafting, neurologic dysfunction, risk factors.

Received: 08.05.2013 - Accepted: 06.07.2013 
ÖZET

Giriş: Bu çalışmanın amacı tek bir merkezde yaşlı hastalarda yapılan koroner baypas ameliyatlarının sonuçlarını analiz etmektir. Postoperatif nörolojik komplikasyonlar ayrıntılı olarak analiz edilmiş ve yaşla beraber diğer risk faktörlerinin nörolojik komplikasyonların oluşumuna etkisi incelenmiştir.

Hastalar ve Yöntem: Bu retrospektif çalışmada 510 koroner baypas hastasının prospektif olarak toplanan verileri analiz edildi. Nörolojik morbidite ve mortalitenin yaşlı hastalarda görülme riski lojistik regresyon analiziyle incelendi.

Bulgular: Çalışmada incelenen 510 hastanın 382 (\%74.9)'si erkekti ve 89 (\%17.5)'u 70 yaşın üzerindeydi. Postoperatif mortalite, pulmoner ve nörolojik komplikasyon sırasıyla 27 (\%5.3), 78 (\%15.3) ve 26 (\%5.1) hastada görüldü. Yetmiş yaş ve altındaki hastalar ile 70 yaş üzerindekilerin karşılaştırılmasında bu değerler arasında istatistiksel olarak anlamlı fark mevcuttu (mortalite \%4.0 ve \% $11.2, p=0.012 ;$ pulmoner morbidite \%13.5 ve \%23.6, $p=0.022$; nörolojik morbidite \%3.3 ve \%13.5, $p=0.0001)$. Serebrovasküler hastalık varlığı (OR= 4.72; $p=0.014)$ ve ileri yaş $(O R=3.55 ; p=0.016)$ nörolojik komplikasyon gelişiminde anlamlı değişkenler olarak bulundu. Hastaların yaşının 51.5 'in üzerinde olduğu her yıl için nörolojik komplikasyon gelişme riskinin \%5.8 artmakta olduğu hesaplandı ( $p=0.049)$.

Sonuç: Yaşı hastalarda yapılan koroner baypas ameliyatları sonrası mortalite, pulmoner ve nörolojik komplikasyonlar daha sık görülmektedir. Yaş ve mortalite arasında anlamlı bir ilişki olmasa da, ileri yaş ve serebrovasküler hastalık nörolojik komplikasyon görülme riskini artırmaktadır.

Anahtar Kelimeler: Koroner arter baypas grefti, nörolojik disfonksiyon, risk faktörleri.

Geliş Tarihi: 08.05.2013 • Kabul Tarihi: 06.07.2013

\section{INTRODUCTION}

The number of elderly patients having coronary bypass operations (CABG) are steadily increasing ${ }^{(1,2)}$. These patients are regarded as high risk group for the higher surgical risks because of the associated high mortality and morbidity rates along with greater length of hospital stay $^{(2,3)}$. Postoperative neurologic events and neuropsychological disorders constitute significant sources of mortality and morbidity after coronary by-pass operations ${ }^{(4,5)}$.

Age is a known risk factor for many postoperative complications in coronary surgery and the outcome results of CABG operations in the elderly have been studied extensively ${ }^{(2,3,6-8)}$. The purpose of this study is to analyze the outcome results in the elderly in a large number of patients from a single institution. The postoperative neurologic complications have been analyzed in detail in order to find out the risk factors and the relation of age and occurrence of neurologic complications has been assessed.

\section{PATIENTS and METHODS}

The rationale for this analysis is the view of our patient sample as a representative cohort of individuals for preoperative assessment units admitting for coronary bypass surgery. Age of the patients was evaluated as an independent risk factor for postoperative mortality and neurologic morbidity.

We have analyzed the hospital records of the patients and our prospectively collected coronary by-pass database after the study was approved by the institutional ethics board and all patient consents were completed. The outcome data of coronary by-pass operations performed from December 1, 2010 to July 31, 2012 were included in the analysis.

We have obtained the preoperative demographic characteristics, operation details and postoperative outcome results from the hospital records and the prospectively collected database. Neurological complication was defined as presence of any cerebrovascular event (stroke, transient ischemic attack or reversible ischemic neurologic deficit) documented by tomography and clinical examination; encephalopathy (onset after $4^{\text {th }}$ postoperative day or lasting more than four days postoperatively in order to rule out effect of anesthesia) and neurologic complications of other causes $^{(9)}$. As a routine preoperative work-up, all patients were evaluated with carotid duplex ultrasonography for presence of any extracranial cerebrovascular disease. In case a hemodynamically significant cerebrovascular disease detected, computerized tomographic (CTA) or magnetic resonance angiography (MRA) was performed. Presence of any cerebrovascular disease was used as a binary variable in the analysis regardless of the hemodynamic significance. Patient demographic characteristics and intraoperative measurements were recorded to the coronary by-pass database by the anesthesiologist.

All patients were operated under general anesthesia and conventional cardiac surgery via median sternotomy was performed. In patients operated for concurrent carotid procedures, carotid procedure was performed prior to sternotomy. Carotid by-pass with saphenous vein graft was used in patients with localized stenosis of internal carotid 
artery. In carotid endarterectomies, carotid shunts were used in each case. Seventy seven (15.1\%) patients were operated off-pump. Cardiopulmonary by-pass was established using a non-pulsatile hypothermic flow of 2.0-2.4 L/ $\mathrm{min} / \mathrm{m}^{2}$, with mean arterial pressure maintained from $50-70$ $\mathrm{mmHg}$ and $\alpha$-stat blood gas management. Pulsatile perfusion was used in 33 patients. Total circulatory arrest was utilized in $3(0.6 \%)$ cases. One of them had graft interposition in the ascending aorta and the other two were operated for aortic root replacement with modified Bentall procedure. They had ascending aortic aneurysms along with coronary artery disease. Axillary arterial cannulation was utilized in these cases and cerebral protection was maintained with selective antegrad cerebroplegia. Arterial cannulation was made on the ascending aorta in the remaining cases. Since we do not have epiaortic ultrasonography available, ascending aorta was assessed intraoperatively by palpation and cannulation was made in the atherosclerosis free areas. According to the procedural needs, myocardial protection was modified as antegrade, retrograde or both using cold or isothermic blood cardioplegia. As a standard cardioplegia strategy we preferred antegrade induction with $1000 \mathrm{~mL}$ at the time of the aortic cross-clamping and afterwards either continuous retrograde or intermittent antegrade (500 mL/20 min) infusion was used until aortic cross-clamp removal. Antifibrinolytic therapy was administered with aminocaproic acid as institutional routine. The intraoperative blood glucose management was made either with bolus or continuous infusions of insulin were administered to obtain a target serum glucose $<200$ $\mathrm{mg} / \mathrm{dL}(11.1 \mathrm{mmol} / \mathrm{L})$. In the postoperative intensive care unit, normoglycemia was achieved following the Portland cardiac surgery insulin protocol ${ }^{(10)}$.

The primary clinical endpoint of this study was postoperative mortality and secondary end point is the occurrence of any neurologic complication after coronary bypass. Patients with diabetes were defined as those with a diagnosis of type 1 or type 2 diabetes mellitus before hospital admission and who were on oral or parenteral hypoglycemic drugs. Renal function was analyzed as a binary variable in the database. We used Acute Kidney Injury Network criteria that was $\geq 50 \%$ postoperative increase from baseline creatinine to peak postoperative creatinine level in the first ten postoperative days ${ }^{(11,12)}$. Pulmonary complication was defined as presence of postoperative respiratory problems necessitating intensive physiotherapy, re-intubation or prolonged mechanical ventilation and presence of pneumothorax or pulmonary effusion. Infectious complications were defined as positive blood, urine, sputum or wound cultures postoperatively, requiring dressings and intravenous antibiotics, requiring revision surgery (like mediastinal infection) or presence of radiographic infiltrate. Gastrointestinal complication was defined as presence of any postoperative complication requiring medical or surgical intervention.

Continuous variables were described as means ( \pm standard deviation) or median (interquartile range) as appropriate; categorical variables were described as a percentage. For descriptive purposes, patients were grouped according to age: $\leq 70$ and $>70$. Logistic regression model was constructed twice with age either as a continuous variable and a binary variable. At the end of the analysis a ROC curve was obtained to assess how well the variable could be discriminated and the area under curve (AUC) was calculated. A logistic regression model for the outcome neurologic morbidity and mortality was constructed with the following dependent predictors: gender, age, previous cerebrovascular event, previous myocardial infarction, hypertension, known diabetes mellitus at the time of admission, hypercholesterolemia, chronic obstructive pulmonary disease (COPD), cerebrovascular disease, family history of coronary disease, peripheral arterial disease (PAD), tobacco use, left ventricular dysfunction (ejection fraction $<40 \%$ ), chronic renal failure at the time of admission, emergency operation, use of pulsatile cardiopulmonary by-pass, off-pump procedure, any concomitant procedure and degree of hypothermia during the operation. The data management and analysis was made with SPSS version 11.0 (SPSS Inc, statistical software package). A p value of 0.05 was considered statistically significant.

\section{RESULTS}

Five hundred and ten patients were operated for CABG during the study period. Of these 510 patients, 382 (74.9\%) were male and 128 (25.1\%) female. The preoperative characteristics were outlined in Table 1 and procedural characteristics were outlined in Table 2.

Postoperative mortality was seen in 27 (5.3\%) of patients and mortality rate was significantly higher in elderly patients (Table 3 ). It can be seen that one patient had delayed awakening (Table 3). This patient was considered to have an encephalopathy since no tomographic changes were present. He had pulmonary and infectious complications and he was discharged on postoperative $52^{\text {nd }}$ day without neurologic sequel. It can be seen that elder patients were extubated later than the younger patients and the incidence of pulmonary complications were signifi- 
Table 1. Preoperative characteristics

\begin{tabular}{|c|c|c|c|c|c|c|}
\hline & $\begin{array}{c}\text { Overall } \\
(n=510)\end{array}$ & $\begin{array}{c}\text { Age } \leq 70 \\
(n=421)\end{array}$ & $\begin{array}{c}\text { Age }>70 \\
(n=89)\end{array}$ & p1* & $\mathrm{p} 2^{* *}$ & $p 3^{\star \star *}$ \\
\hline Age & $60.6 \pm 9.9(34-86)$ & $57.4 \pm 7.6$ & $75.6 \pm 3.6$ & 0.0001 & 0.426 & 0.016 \\
\hline Gender & & & & 0.0001 & 0.697 & 0.287 \\
\hline Male & $382(74.9 \%)$ & $329(78.1 \%)$ & $53(59.6 \%)$ & & & \\
\hline Female & $128(25.1 \%)$ & $92(21.9 \%)$ & 36 (40.4\%) & & & \\
\hline BMI $\left(\mathrm{kg} / \mathrm{m}^{2}\right)$ & $27.6 \pm 4.1(18-40)$ & $27.8 \pm 4.2$ & $27.7 \pm 3.9$ & 0.827 & - & - \\
\hline Previous cardiac surgery & $4(0.8 \%)$ & $3(0.7 \%)$ & $1(1.1 \%)$ & 0.537 & - & - \\
\hline Previous MI & $151(29.6 \%)$ & $125(29.8 \%)$ & $26(29.2 \%)$ & 0.907 & 0.725 & 0.277 \\
\hline Preoperative EF (\%) & $50.6 \pm 8.8(30-60)$ & $50.7 \pm 8.7$ & $50.3 \pm 9.2$ & 0.676 & - & - \\
\hline LVD $(E F<40 \%)$ & $97(19.0 \%)$ & $77(18.3 \%)$ & $20(22.5 \%)$ & 0.369 & 0.900 & 0.148 \\
\hline Hypertension & $277(54.3 \%)$ & $222(52.7 \%)$ & $55(61.8 \%)$ & 0.117 & 0.222 & 0.115 \\
\hline Previous CVE & $23(4.5 \%)$ & $15(3.6 \%)$ & $8(9.0 \%)$ & 0.041 & 0.050 & 0.201 \\
\hline CVD & $45(8.8 \%)$ & $30(7.1 \%)$ & 15 (16.9\%) & 0.007 & 0.270 & 0.014 \\
\hline COPD & $122(23.9 \%)$ & $101(24.0 \%)$ & $21(23.6 \%)$ & 0.937 & 0.249 & 0.628 \\
\hline Known diabetes mellitus & $205(40.2 \%)$ & $176(41.8 \%)$ & 29 (32.6\%) & 0.103 & 0.549 & 0.162 \\
\hline Hypercholesterolemia & $293(57.5 \%)$ & 247 (58.7\%) & 46 (51.7\%) & 0.228 & 0.104 & 0.274 \\
\hline Tobacco use & $258(50.6 \%)$ & $239(56.8 \%)$ & $19(21.3 \%)$ & 0.0001 & 0.983 & 0.115 \\
\hline Family history for CAD & $219(42.9 \%)$ & $185(43.9 \%)$ & 34 (38.2\%) & 0.318 & 0.113 & 0.281 \\
\hline Preoperative CRF & $23(4.5 \%)$ & $18(4.3 \%)$ & $5(5.7 \%)$ & 0.560 & 0.261 & 0.228 \\
\hline PAD & $51(10.0 \%)$ & $39(9.3 \%)$ & $12(13.5 \%)$ & 0.248 & 0.786 & 0.644 \\
\hline Preoperative $\mathrm{Hb}(\mathrm{mg} / \mathrm{dL})$ & $12.4 \pm 1.6(7.0-17.0)$ & $12.6 \pm 1.6$ & $11.8 \pm 1.6$ & 0.0001 & - & - \\
\hline Preoperative Htc (\%) & $37.9 \pm 6.2(16.0-54.0)$ & $38.2 \pm 6.3$ & $36.9 \pm 5.7$ & 0.086 & - & - \\
\hline
\end{tabular}

BMI: Body mass index, CAD: Coronary artery disease, COPD: Chronic obstructive pulmonary disease, CRD: Chronic renal disease, CVD: Cerebrovascular disease, CVE: Cerebrovascular event, PAD: Peripheral arterial disease, EF: Ejection fraction, Hb: Hemoglobine, Htc: Hematocrite, LVD: Left ventricular dysfunction, MI: Myocardial infarction.

${ }^{*} p$ values for univariate analyses.

** $p$ values for logistic regression analysis for mortality.

${ }^{* * *} p$ values for logistic regression analysis for neurologic mortality.

cantly higher (Table 3). However, the incidences of pulmonary complications were not significantly different among groups in patients with neurologic morbidity (Table 4).

The data of the patients with neurologic complications were summarized in Table 4. Facial paralysis was seen in two patients over 70 years of age. They had carotid endarterectomy concurrent with coronary by-pass. The facial paralysis was attributed to the intraoperative retraction of the facial nerve and the patient had complete recovery during their follow-up in the outpatient clinic. None of the patients who had valvular operations or operated with total circulatory arrest had any neurologic complication. None of the patients with total circulatory arrest had any neurological morbidity but the number is too small to draw significant conclusions. Of the 23 patients who had a history of previous cerebrovascular event, only 3 of them had postoperative neurologic complications. All three were over 70 years of age and none of them had stroke. Two had facial paralysis and one had encephalopathy. The patient with encephalopathy died because of pneumonia. Of the 45 patients with cerebrovascular disease, seven patients had postoperative neurologic complication. Three of them had postoperative cerebrovascular event, two had facial paralysis, one had encephalopathy and one showed delayed awakening. Two of them (with stroke) had mortality. The patients with mortality had isolated CABG procedure and the etiology for mortality was massive stroke in one and low cardiac output in the other. 


\begin{tabular}{|c|c|c|c|c|c|c|}
\hline & Overall & $\begin{array}{r}\text { Age } \leq 70 \\
(n=421)\end{array}$ & $\begin{array}{c}\text { Age }>70 \\
(n=89)\end{array}$ & p1* & $\mathrm{p} 2^{\star *}$ & $\mathrm{p} 3^{\star \star *}$ \\
\hline $\begin{array}{l}\text { Number of distal } \\
\text { anastomosis }\end{array}$ & $2.8 \pm 1.0(1-6)$ & $2.9 \pm 1.0$ & $2.8 \pm 1.0$ & 0.607 & - & - \\
\hline Concomitant procedure & $39(7.6 \%)$ & $26(6.2 \%)$ & $13(14.6 \%)$ & 0.012 & 0.641 & 0.342 \\
\hline Valve procedure & $19(3.7 \%)$ & $15(3.6 \%)$ & $4(4.5 \%)$ & 0.757 & - & - \\
\hline Carotid procedure & $6(1.2 \%)$ & $4(1.0 \%)$ & $2(2.2 \%)$ & 0.283 & - & - \\
\hline Emergency operation & $67(13.1 \%)$ & $58(13.8 \%)$ & $9(10.1 \%)$ & 0.335 & 0.685 & 0.914 \\
\hline OPCAB & $77(15.1 \%)$ & $66(15.7 \%)$ & $11(12.4 \%)$ & 0.417 & 0.961 & 0.863 \\
\hline Pulsatile CPB & $33(6.5 \%)$ & $32(7.6 \%)$ & $1(1.1 \%)$ & 0.018 & 0.444 & 0.576 \\
\hline ACC duration (min) & $61.8 \pm 30.9(11-235)$ & $61.0 \pm 30.1$ & $65.9 \pm 34.1$ & 0.195 & - & - \\
\hline CPB duration (min) & $100.6 \pm 41.5(18-392)$ & $99.7 \pm 39.4$ & $105.1 \pm 50.4$ & 0.284 & - & - \\
\hline Intraoperative bleeding $(\mathrm{mL})$ & $541.7 \pm 180.5(100-1500)$ & $540.0 \pm 181.8$ & $549.4 \pm 174.9$ & 0.655 & - & - \\
\hline $\begin{array}{l}\text { Intraoperative use of blood } \\
\text { products }\end{array}$ & & & & & - & - \\
\hline ES (U) & $0.6 \pm 0.9(0-5)$ & $0.5 \pm 0.8$ & $0.9 \pm 1.0$ & 0.0001 & & \\
\hline $\mathrm{FFP}(\mathrm{U})$ & $1.4 \pm 0.9(0-4)$ & $1.4 \pm 0.9$ & $1.6 \pm 1.0$ & 0.182 & & \\
\hline FWB (U) & $0.7 \pm 0.7(0-10)$ & $0.7 \pm 0.7$ & $0.8 \pm 0.6$ & 0.096 & & \\
\hline $\begin{array}{l}\text { Postoperative use of blood } \\
\text { products }\end{array}$ & & & & & - & - \\
\hline$E S(U)$ & $1.6 \pm 1.6(0-10)$ & $1.5 \pm 1.5$ & $2.2 \pm 2.1$ & 0.021 & & \\
\hline FFP (U) & $1.7 \pm 1.8(0-14)$ & $1.6 \pm 1.5$ & $2.1 \pm 2.6$ & 0.072 & & \\
\hline FWB (U) & $0.7 \pm 0.7(0-3)$ & $0.7 \pm 0.7$ & $0.8 \pm 0.8$ & 0.131 & & \\
\hline Hypothermia $\left({ }^{\circ} \mathrm{C}\right)$ & $30.3 \pm 1.4(18-36)$ & $30.3 \pm 1.2$ & $30.0 \pm 2.1$ & 0.134 & 0.948 & 0.677 \\
\hline Use of TCA & $3(0.6 \%)$ & $1(0.1 \%)$ & $2(2.2 \%)$ & 0.080 & - & - \\
\hline
\end{tabular}

The logistic regression analysis was run twice; one for age as a continuous variable and the other for age as a binary variable ( $\leq 70$ and $>70$ ). Advanced age was significantly associated with postoperative neurologic complication in each run. Advanced age was associated with neurologic complications with an odds ratio (OR) of 3.55 [95\% confidence interval $(\mathrm{Cl})=1.27-9.90 ; \mathrm{p}=0.016]$. Every year increase above 51.5 is associated with $5.8 \%$ (95\% $\mathrm{Cl}=0.1 \%-11.9 \% ; \mathrm{p}=0.049$ ) increased neurologic complication risk. The ROC curve also showed $92.0 \%$ sensitivity with statistical significance (area under curve $=0.702,95 \%$ $\mathrm{Cl}=0.599-0.804 ; \mathrm{p}=0.001$ ) (Figure 1). The other significant associations with postoperative neurologic complica- tion was presence of cerebrovascular disease $(\mathrm{OR}=4.72)$ (95\% Cl=1.38-16.13; $\mathrm{p}=0.014)$.

\section{DISCUSSION}

In this study, we evaluated the outcome data of heterogeneous group of patients operated for CABG for comparison between elderly and younger patients. The result of the analysis revealed marked difference of neurologic complications in elderly patients $(p=0.0001)$. The main difference between the groups was related to the more frequent occurrence of encephalopathy in elderly patients. The significance of age persisted in the multivariate analysis and $5.8 \%$ risk increase was found for every year increase in patients older than 51.5 years of age. 


\begin{tabular}{|c|c|c|c|c|}
\hline & $\begin{array}{c}\text { Overall } \\
(n=510)\end{array}$ & $\begin{array}{r}\text { Age } \leq 70 \\
(n=421)\end{array}$ & $\begin{array}{c}\text { Age }>70 \\
(n=89)\end{array}$ & $\mathbf{p}^{*}$ \\
\hline Mortality & $27(5.3 \%)$ & $17(4.0 \%)$ & $10(11.2 \%)$ & 0.012 \\
\hline ICU stay (days) & $3.8 \pm 3.3(1-36)$ & $3.5 \pm 2.6$ & $4.0 \pm 2.2$ & 0.146 \\
\hline Total hospital stay (days) & $8.9 \pm 6.9(1-69)$ & $7.6 \pm 5.5$ & $9.0 \pm 8.1$ & 0.157 \\
\hline Time to extubation (hours) & $9.5 \pm 8.6(2-124)$ & $9.1 \pm 8.4$ & $11.6 \pm 9.0$ & 0.017 \\
\hline Any morbidity & $237(46.5 \%)$ & $186(44.3 \%)$ & $51(57.3 \%)$ & 0.025 \\
\hline Arrhythmia** & $85(16.7 \%)$ & $69(16.4 \%)$ & $16(18.0 \%)$ & 0.717 \\
\hline AF & $76(14.9 \%)$ & $60(14.3 \%)$ & $16(18.0 \%)$ & 0.380 \\
\hline Persistent AF & $17(3.3 \%)$ & $12(2.9 \%)$ & $5(5.6 \%)$ & 0.217 \\
\hline Pulmonary & $78(15.3 \%)$ & $57(13.5 \%)$ & $21(23.6 \%)$ & 0.022 \\
\hline Renal & $39(7.6 \%)$ & $31(7.4 \%)$ & $8(9.0 \%)$ & 0.607 \\
\hline Need for dialysis & $13(2.5 \%)$ & $9(2.1 \%)$ & $4(4.5 \%)$ & 0.256 \\
\hline Neurological & $26(5.1 \%)$ & $14(3.3 \%)$ & $12(13.5 \%)$ & 0.0001 \\
\hline Encephalopathy & $9(1.8 \%)$ & $5(1.2 \%)$ & $7(7.9 \%)$ & \\
\hline Hepatic encephalopathy & $2(0.4 \%)$ & $2(0.5 \%)$ & 0 & \\
\hline Delayed awakening & $1(0.2 \%)$ & 0 & $1(0.2 \%)$ & \\
\hline CVE & $10(2.0 \%)$ & $8(1.9 \%)$ & $2(2.2 \%)$ & \\
\hline Facial paralysis & $3(0.6 \%)$ & 0 & $3(3.4 \%)$ & \\
\hline Convulsion & $1(0.2 \%)$ & $1(0.2 \%)$ & 0 & \\
\hline Ischemic ECG change & $17(3.3 \%)$ & $14(3.3 \%)$ & $3(3.4 \%)$ & 1.000 \\
\hline Low cardiac output & $21(4.1 \%)$ & $14(3.3 \%)$ & $7(7.9 \%)$ & 0.072 \\
\hline Need for inotropic support & $49(9.6 \%)$ & $37(8.8 \%)$ & $12(13.5 \%)$ & 0.190 \\
\hline Need for IABP support & $15(2.9 \%)$ & $11(2.6 \%)$ & $4(4.5 \%)$ & 0.311 \\
\hline Revision surgery for bleeding & $23(4.5 \%)$ & $18(4.3 \%)$ & $5(5.6 \%)$ & 0.590 \\
\hline Tamponade & $11(2.2 \%)$ & $10(2.4 \%)$ & $1(1.1 \%)$ & 0.699 \\
\hline Infection & $30(4.9 \%)$ & $21(5.0 \%)$ & $9(10.1 \%)$ & 0.082 \\
\hline Mediastinitis & $6(1.2 \%)$ & $3(0.7 \%)$ & $3(3.4 \%)$ & 0.069 \\
\hline Sternal dehiscence & $9(1.8 \%)$ & $8(1.9 \%)$ & $1(1.1 \%)$ & 1.000 \\
\hline Gastrointestinal morbidity & $16(3.1 \%)$ & $15(3.6 \%)$ & $1(1.1 \%)$ & 0.328 \\
\hline Readmission to ICU & $21(4.1 \%)$ & $17(4.0 \%)$ & $4(4.5 \%)$ & 0.773 \\
\hline
\end{tabular}

AF: Atrial fibrillation; CVE: Cerebrovascular event; IABP: Intraaortic balloon counterpulsation; ICU: Intensive care unit; TND: Transient neurologic dysfunction.

* Independent samples t-test or chi-square or Fisher's exact test.

** Occurrence of any heart rhythm disorder.

Aortic atheroma is a well known risk factor for stroke and it has been postulated that it may have significant correlation with postoperative neurocognitive dysfunction ${ }^{(13)}$. We do not analyze the cognitive functions routinely in our daily practice. Patients were evaluated for their mental status as a part of routine daily examination and mainly the distinctive alterations detected in the physical exami- nations were noted. A detailed analysis of neurocognitive function may reveal higher incidences in both groups. Cognitive dysfunction was reported to be decreasing in the early postoperative period and the amount of decline was shown to be correlated with delayed or absence recovery of such functions ${ }^{(14)}$. The incidence of cerebrovascular event was $2 \%$ in the overall cohort and groups did 


\begin{tabular}{|c|c|c|c|c|}
\hline & $\begin{array}{l}\text { Overall* } \\
(n=26)\end{array}$ & $\begin{array}{c}\text { Age } \leq 70 \\
(n=14)\end{array}$ & $\begin{array}{c}\text { Age }>70 \\
(n=12)\end{array}$ & $\mathbf{p}^{\#}$ \\
\hline \multicolumn{5}{|l|}{ PREOPERATIVE } \\
\hline Age & $70(61-75)$ & 63 & 75 & 0.0001 \\
\hline Concurrent procedure ${ }^{* *}$ & $2(7.7 \%)$ & 0 & $2(16.7 \%)$ & 0.203 \\
\hline Number of distal anastomoses & $3(3-4)$ & 4 & 3 & 0.560 \\
\hline Emergency procedure & $3(11.5 \%)$ & $2(14.3 \%)$ & $1(8.3 \%)$ & 1.000 \\
\hline Hypertension & $20(76.9 \%)$ & $12(85.7 \%)$ & $8(66.7 \%)$ & 0.365 \\
\hline Known diabetes mellitus & $10(38.5 \%)$ & $6(42.9 \%)$ & $4(33.3 \%)$ & 0.701 \\
\hline Hypercholesterolemia & $15(57.7 \%)$ & $8(57.1 \%)$ & $7(58.3 \%)$ & 0.951 \\
\hline Previous CVE & $3(11.5 \%)$ & 0 & $3(25 \%)$ & 0.085 \\
\hline Presence of CVD & 7 (26.9\%) & $3(21.4 \%)$ & $4(33.3 \%)$ & 0.665 \\
\hline PAD & $3(11.5 \%)$ & $1(7.1 \%)$ & $2(16.7 \%)$ & 0.580 \\
\hline Chronic renal failure & $3(11.5 \%)$ & $1(7.1 \%)$ & $2(16.7 \%)$ & 0.580 \\
\hline COPD & $7(26.9 \%)$ & $5(35.7 \%)$ & $2(16.7 \%)$ & 0.391 \\
\hline Tobacco use & $7(26.9 \%)$ & $6(42.9 \%)$ & $1(8.3 \%)$ & 0.081 \\
\hline Family history of CAD & 9 (34.6\%) & $7(50.0 \%)$ & $2(16.7 \%)$ & 0.110 \\
\hline Previous MI & $6(23.1 \%)$ & $4(28.6 \%)$ & $2(16.7 \%)$ & 0.652 \\
\hline EF (\%) & $50(40-60)$ & $47 \%$ & $58 \%$ & 0.212 \\
\hline LVD $(E F<40 \%)$ & $8(30.8 \%)$ & $6(42.9 \%)$ & $2(16.7 \%)$ & 0.216 \\
\hline \multicolumn{5}{|l|}{ PROCEDURAL } \\
\hline OPCAB & $6(23.1 \%)$ & $4(28.6 \%)$ & $2(16.7 \%)$ & 0.652 \\
\hline Pulsatile CPB & $2(7.7 \%)$ & $2(14.3 \%)$ & 0 & 0.483 \\
\hline $\mathrm{ACC}(\mathrm{min})$ & $61(44-73)$ & 70 & 60 & 0.260 \\
\hline CPB duration (min) & $106(79-134)$ & 117 & 88 & 0.347 \\
\hline Hypothermia $\left({ }^{\circ} \mathrm{C}\right)$ & $30(30-30)$ & 30 & 30 & 0.695 \\
\hline \multicolumn{5}{|l|}{ POSTOPERATIVE } \\
\hline Time to extubation (hours) & $10.0(7.5-11.0)$ & 8 & 10 & 0.251 \\
\hline ICU stay (days) & $4(3-9)$ & 4 & 4 & 0.824 \\
\hline Hospital stay (days) & $11(7-26)$ & 13 & 9 & 0.882 \\
\hline Mortality & $5(19.2 \%)$ & $3(21.4 \%)$ & $2(16.7 \%)$ & 1.000 \\
\hline Any morbidity ${ }^{* \star *}$ & $19(73.1 \%)$ & $10(71.4 \%)$ & $9(75.0 \%)$ & 1.000 \\
\hline Arrhythmia (AF) & $7(26.9 \%)$ & $3(21.4 \%)$ & $4(33.3 \%)$ & 0.665 \\
\hline Persistent AF & $2(7.7 \%)$ & $2(14.3 \%)$ & 0 & 0.483 \\
\hline Pulmonary & $15(57.7 \%)$ & $8(57.1 \%)$ & $7(58.3 \%)$ & 0.951 \\
\hline Renal & $6(23.1 \%)$ & $4(28.6 \%)$ & $2(16.7 \%)$ & 0.652 \\
\hline Need for dialysis & $3(11.5 \%)$ & $2(14.3 \%)$ & $1(8.3 \%)$ & 1.000 \\
\hline Ischemic ECG change & $1(3.8 \%)$ & $1(7.1 \%)$ & 0 & 1.000 \\
\hline Low cardiac output & $5(19.2 \%)$ & $3(21.4 \%)$ & $2(16.7 \%)$ & 1.000 \\
\hline Need for inotropic support & $7(26.9 \%)$ & $4(28.6 \%)$ & $3(25.0 \%)$ & 1.000 \\
\hline Need for IABP support & $1(3.8 \%)$ & $1(7.1 \%)$ & 0 & 1.000 \\
\hline
\end{tabular}


Effect of Age on Postoperative Results in Elderly Coronary By-pass Patients

Koroner Baypas Hastalarında Postoperatif Sonuçlara Yaşın Etkileri

Table 4. Patients with neurologic morbidity (continue)

\begin{tabular}{|c|c|c|c|c|}
\hline & $\begin{array}{l}\text { Overall }^{*} \\
(n=26)\end{array}$ & $\begin{array}{c}\text { Age } \leq 70 \\
(n=14)\end{array}$ & $\begin{array}{c}\text { Age }>70 \\
(n=12)\end{array}$ & $\mathbf{p}^{\#}$ \\
\hline Revision surgery for bleeding & $2(7.7 \%)$ & $1(7.1 \%)$ & $1(8.3 \%)$ & 1.000 \\
\hline Tamponade & $2(7.7 \%)$ & $1(7.1 \%)$ & $1(8.3 \%)$ & 1.000 \\
\hline Infection & $8(30.8 \%)$ & $3(21.4 \%)$ & $5(41.7 \%)$ & 0.401 \\
\hline Mediastinitis & $3(11.5 \%)$ & $2(14.3 \%)$ & $1(8.3 \%)$ & 1.000 \\
\hline Sternal dehiscence & $3(11.5 \%)$ & $2(14.3 \%)$ & $1(8.3 \%)$ & 1.000 \\
\hline Gastrointestinal morbidity & $3(11.5 \%)$ & $3(21.0 \%)$ & 0 & 0.225 \\
\hline Readmission to ICU & $9(34.6 \%)$ & $7(50 \%)$ & $2(16.7 \%)$ & 0.110 \\
\hline
\end{tabular}

ACC: Aortic cross clamp, AF: Atrial fibrillation, COPD: Chronic obstructive pulmonary disease, CPB: Cardiopulmonary by-pass, CVD: Extracranial cerebrovascular disease, CVE: Cerebrovascular event, EF: Ejection fraction, LVD: Left ventricular dysfunction, MI: Myocardial infarction, OPCAB: Offpump coronary by-pass, PAD: Peripheral arterial disease, SD: Standard deviation.

* Median (interquartile range)/n (\%)

** Carotid endarterectomy.

*** Except neurologic morbidity.

\# Mann-Whitney U test, chi-square or Fisher's exact test.

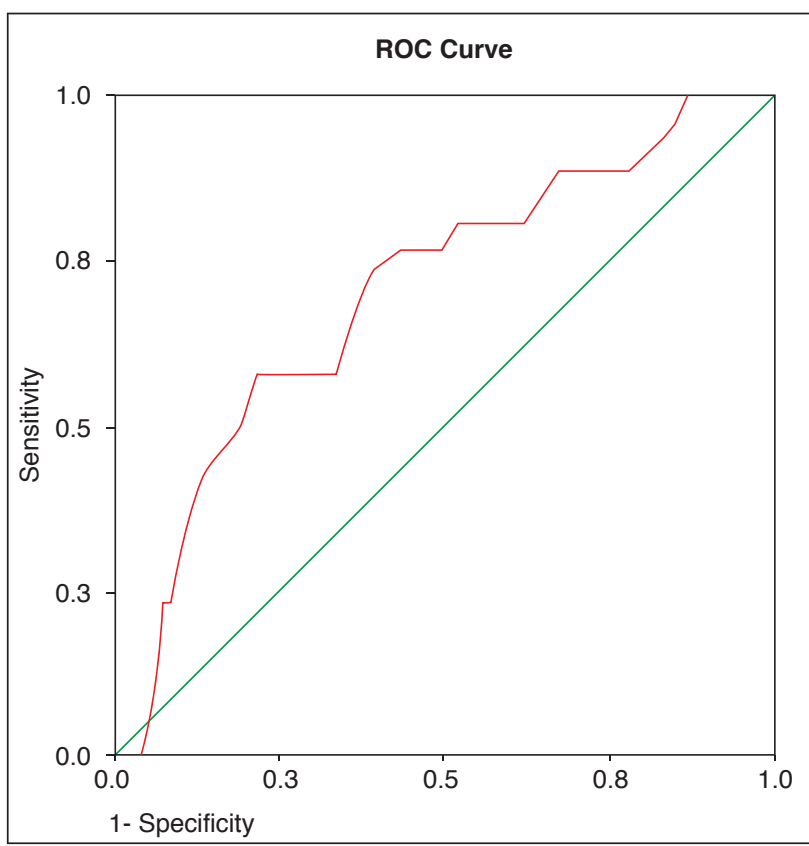

Figure 1. ROC curve graph for age cut-off point.

not show significant difference. The results were similar to previous reports ${ }^{(2,15)}$. Goto and colleagues analyzed the relation of arteriosclerosis severity and postoperative neurologic morbidity in patients older than 60 years of age ${ }^{(16)}$ The grouped the patients according to the degree of arteriosclerosis of the ascending aorta. The incidences of stroke in normal or mild, moderate and severe arteriosclerosis were $10.5 \%, 7 \%$ and $1.8 \%$, respectively ${ }^{(16)}$. It was previously stated that (in the methods section) we did not use epiaortic ultrasound intraoperatively. However, the incidence of cerebrovascular event in our study group $\mathrm{s}$ compatible with the normal or mild arteriosclerosis group in the aforementioned study ${ }^{(16)}$. This may be related to the fact that our study group is a heterogeneous group of patients admitted for CABG in our clinic.

Apart from cerebrovascular event, other neurologic complications constitute important sources of postoperative morbidity. A recent analysis showed that low mini mental state examination score and high creatinine values preoperatively and prolonged cardiopulmonary by-pass durations were predictors of postoperative delirium in the elderly patients ${ }^{(17)}$. Bucerius and colleagues analyzed the predictors of postoperative delirium in cardiac surgery patients $^{(5)}$. In the aforementioned analysis of more than 16.000 patients, the prevalence of delirium was $8.4 \%$ and $16.2 \%$ of these cases had postoperative stroke. The prevalence of postoperative delirium was reported to be higher in patients over 70 years of age (12.9\%) and lower after off-pump coronary by-pass operations (5.1\%). Unlike their analysis, we did not detect significant associations with off-pump operations in our series. No-touch strategies have been postulated to be more important in occurrence of neurologic complications ${ }^{(16)}$. The use of pulsatile cardiopulmonary by-pass also did not have any significant effect. So, this analysis does not add any additional information on the contradictory results of pulsatile cardiopulmonary by-pass literature, however, the number of patients is small draw meaningful conclusions ${ }^{(18)}$. The patients with postoperative delirium had higher rates of pulmonary prob- 
lems, sternum instability and longer duration of intensive care stays. However, as indicated in Table 4, the extraneurologic morbidity was similar in elderly and younger patients in our study group. So, the latter associations may be independent of patient's age unlike the occurrence of neurologic morbidity. The higher prevalence of encephalopathy constitutes the major difference between the age groups (Table 3) in our study. Excluding the two patients with hepatic encephalopathy in the younger patients, the significance will be greater. In our analysis, we analyzed the patients with neurologic morbidities according to the age groups (Table 4). Elderly patients did not show significant differences of morbidity (other than neurologic) than the younger counterparts. The overall group comparisons (Table 3), however, revealed significant differences in terms of mortality, extubation times, neurologic and pulmonary morbidity. Considering the fact that age persisted as a significant risk factor in the multivariate analysis, the higher neurologic morbidity should be explained by some other mechanisms.

The preoperative characteristics were summarized in Table 1. It can be seen that the prevalence of a previous cerebrovascular event and presence of extracranial cerebrovascular disease was higher in the elderly patients. Presence of cerebrovascular disease was also significantly associated with postoperative neurologic morbidity in regression analysis unlike presence of a history of cerebrovascular event. This may be due to the fact that, lower perfusion may be a more important factor. The association of age and neurologic morbidity may be due to the lower reserve in elderly patients. Although there was lack of association of atherosclerotic parameters with neurologic morbidity (peripheral arterial disease, diabetes mellitus, hypertension, and hypercholesterolemia), the higher incidence of cerebrovascular disease and significant association in regression analysis may still favor the importance of atherosclerotic process. The prevalence of hemodynamically significant cerebrovascular disease was reported to be between $12 \%$ and $17 \%{ }^{(19)}$. Our patient cohort had lower rates overall but the patients over 70 years of age had compatible rates. The risk of perioperative stroke was reported to be lower than $2 \%$ in the absence of cerebrovascular disease $^{(19)}$. This is compatible with the cerebrovascular event rate in the overall group cerebrovascular event prevalence. Although more up to $10 \%$ stroke rates were reported for the concomitant CABG and carotid procedures, we did not have perioperative cerebrovascular event in these concomitant cases $^{(19,20)}$. Still, the expected stroke rates are higher than $2.4 \%$ in combined procedures ${ }^{(19)}$. Combined procedures did not have significant associations with mortality or neurologic morbidity in our study group (Table 2). Another importance of cerebrovascular disease may be the importance of lower perfusion and lower reserve in elderly patients. Another important factor was the blood transfusion. It can be seen that elderly patients had lower preoperative hemoglobin values (Table 1) and higher need of erythrocyte transfusions (Table 2). Bucerius et al. also reported increased risk of delirium with high transfusion requirements in cardiac surgery patients ${ }^{(5)}$.

Another important finding was the higher prevalence of pulmonary complications in elderly patients. It could be objected that the pulmonary complications were too high. This difference was mainly due to the definition of pulmonary complications. Many studies reporting lower numbers consider mostly respiratory failure patients. A more strict definition of pulmonary morbidity was given in the methods section. Even the patients requiring prolonged respiratory physiotherapy were accepted morbid in this analysis. Again, with any definition, older patients were reported to have higher pulmonary problems ${ }^{(1,21)}$. In spite of this high morbidity, satisfactory mid and long results have been re$\operatorname{ported}^{(2,7)}$.

The patient population that was analyzed is a heterogeneous group of patients. Patients who had concomitant procedures were included in the analysis in order to simulate a real-world situation. It can be seen from our data that a significant number of patients (about $8 \%$ ) had concomitant procedures. As it may be a limiting factor in interpreting the results, it has other advantages. First, we tried to make a risk assessment for neurologic complications in CABG patients. It can be seen that, elderly patients had concomitant procedures significantly more often (Table 2 ). So, we used this fact intentionally in order to analyze this variable as a separate variable in the regression analysis. Our results confirm our hypothesis that concomitant procedures do not pose an additional risk on the neurologic outcome.

In conclusion, elderly patients have higher rates of mortality, pulmonary and neurologic morbidity after CABG operations. Although no significant associations were found between age and mortality, age constitutes an independent risk factor for neurologic morbidity along with presence cerebrovascular disease.

\section{CONFLICT Of INTEREST}

None declared. 


\section{REFERENCES}

1. Bardakci H, Cheema FH, Topkara VK, Dang NC, Martens TP, Mercando $M L$, et al. Discharge to home rates are significantly lower for octogenarians undergoing coronary artery bypass graft surgery. Ann Thorac Surg 2007;83:483-9.

2. Polat A, Tekümit $H$, Cenal AR, Tataroğlu $C$, Uzun K, Mert B, et al. Mid-term results of coronary artery bypass graft surgery in patients 70 years of age or older. Turkish J Thorac Cardiovasc Surg 2012;20:467-73.

3. Katz NM, Hannan RL, Hopkins RA, Wallace RB. Cardiac operations in patients aged 70 years and over: mortality, length of stay, and hospital charge. Ann Thorac Surg 1995;60:96-100.

4. Halkos ME, Puskas JD, Lattouf OM, Kilgo P, Guyton RA, Thourani $\mathrm{VH}$. Impact of preoperative neurologic events on outcomes after coronary artery bypass grafting. Ann Thorac Surg 2008;86:50410.

5. Bucerius J, Gummert JF, Borger MA, Walther T, Doll N, Falk $V$, et al. Predictors of delirium after cardiac surgery delirium: effect of beating-heart (off-pump) surgery. J Thorac Cardiovasc Surg 2004;127:57-64.

6. Tokmakoglu H, Kandemir Ö, Farsak B, Günaydın S, Aydın H, Yorgancıoğlu $C$, et al. Yetmişbeş yaş üstü hastalarda koroner baypass cerrahisi ve sonuçları. Türk Kardiyol Der Ars 2002;30:73742.

7. Chaturvedi RK, Blaise M, Verdon J, lqbal S, Ergina P, Cecere R, et al. Cardiac surgery in octogenarians: long-term survival, functional status, living arrangements, and leisure activities. Ann Thorac Surg 2010;89:805-10.

8. Sen B, Niemann $B$, Roth $P$, Aser $R$, Schönburg $M$, Böning $A$. Short- and long-term outcomes in octogenarians after coronary artery bypass surgery. Eur J Cardiothorac Surg 2012;42:e102-7.

9. Breuer AC, Furlan AJ, Hanson MR, Lederman RJ, Loop FD, Cosgrove DM, et al. Central nervous system complications of coronary artery bypass graft surgery: prospective analysis of 421 patients. Stroke 1983;14:682-7.

10. Furnary AP, Zerr KJ, Grunkemeier GL, Starr A. Continuous intravenous insulin infusion reduces incidence of deep sternal wound infection in diabetic cardiac surgery patients. Ann Thorac Surg 1999;67:352-62.

11. Lopes JA, Fernandes $P$, Jorge S, Goncalves S, Alvarez A, Costa e Silva $Z$, et al. Acute kidney injury in intensive care unit patients: a comparison between the RIFLE and the Acute Kidney Injury Network classifications. Crit Care 2008;12:R110.
12. Bellomo R, Ronco C, Kellum JA, Mehta RL, Palevsky P; Acute Dialysis Quality Initiative workgroup. Acute renal failure-definition, outcome measures, animal models, fluid therapy and information technology needs: the Second International Consensus Conference of the Acute Dialysis Quality Initiative (ADQI) Group. Crit Care 2004;8:R204-12.

13. Bar-Yosef S, Anders M, Mackensen GB, Ti LK, Mathew JP, Phillips-Bute B, et al; Neurological Outcome Research Group and CARE Investigators of the Duke Heart Center. Aortic atheroma burden and cognitive dysfunction after coronary artery bypass graft surgery. Ann Thorac Surg 2004;78:1556-62.

14. Newman MF, Kirchner JL, Phillips-Bute B, Gaver V, Grocott H, Jones $R H$, et al; Neurological Outcome Research Group and the Cardiothoracic Anesthesiology Research Endeavors Investigators. Longitudinal assessment of neurocognitive function after coronary-artery bypass surgery. N Engl J Med 2001;344:395-402.

15. Misfeld M, Brereton RJ, Sweetman EA, Doig GS. Neurologic complications after off-pump coronary artery bypass grafting with and without aortic manipulation: meta-analysis of 11,398 cases from 8 studies. J Thorac Cardiovasc Surg 2011;142:e11-7.

16. Goto T, Baba T, Matsuyama K, Honma K, Ura M, Koshiji T. Aortic atherosclerosis and postoperative neurological dysfunction in elderly coronary surgical patients. Ann Thorac Surg 2003;75:19128.

17. Bakker RC, Osse RJ, Tulen JH, Kappetein AP, Bogers AJ. Preoperative and operative predictors of delirium after cardiac surgery in elderly patients. Eur J Cardiothorac Surg 2012;41:544-9.

18. Hogue CW Jr, Palin CA, Arrowsmith JE. Cardiopulmonary bypass management and neurologic outcomes: an evidence-based appraisal of current practices. Anesth Analg 2006;103:21-37.

19. Venkatachalam S, Gray BH, Mukherjee D, Shishehbor MH. Contemporary management of concomitant carotid and coronary artery disease. Heart 2011;97:175-80.

20. Yildirim T, Akgün S, Sur H, Kinikoglu H, Bilgin F, Arsan S. Shortterm results of simultaneous carotid endarterectomy and myocardial revascularization. Turkish $J$ Thorac Cardiovasc Surg 2004;12:156-60.

21. Gatti G, Cardu G, Lusa AM, Pugliese P. Predictors of postoperative complications in high-risk octogenarians undergoing cardiac operations. Ann Thorac Surg 2002;74:671-7. 